\title{
PENGARUH HIPNOSIS TERHADAP TINGKAT KECEMASAN IBU POST SECTIO CAESAREA
}

\author{
Wilda Nurul Fadilah, Meti Megawati, Endang Astiriyani \\ Jurusan Kebidanan Poltekkes Kemenkes Tasikmalaya \\ wildanurulfadilah@gmail.com
}

\begin{abstract}
ABSTRAK
Sectio caesarea adalah salah satu cara melahirkan, dampak secara fisik akan menyebabkan rasa nyeri pada abdomen dan secara psikologis berdampak terhadap rasa takut dan cemas terhadap nyeri yang dirasakan. Rasa cemas yang berkelanjutan dapat menyebabkan stres, post partum blues bahkan psikosis. Salah satu upaya untuk mengurangi tingkat kecemasan adalah menggunakan hipnosis. Tujuan penelitian ini untuk mengetahui pengaruh hipnosis terhadap tingkat kecemasan ibu post sectio caesarea di Ruang Marwah Rumah Sakit Singaparna Medika Citrautama Kabupaten Tasikmalaya. Penelitian ini menggunakan quasi experimental design, dengan pendekatan one group pretest-postest design. Penelitian dilakukan pada 10 Januari 2018 - 10 Maret 2018 dengan jumlah populasi 127 orang dan sampel 30 orang berdasarkan kriteria inklusi (dijelaskan inklusi dan eksklusinya). Variabel bebas dalam penelitian ini hipnosis sedangkan variabel terikat tingkat kecemasan ibu post sectio caesarea. Pengolahan data menggunakan uji Wilcoxon. Berdasarkan hasil uji statistik terdapat perbedaan yang signifikan antara hasil pretest-postest dengan tingkat signifikasi $\rho$ value $0,001<0,05$, yang berarti hipnosis berpengaruh terhadap tingkat kecemasan. Penelitian ini tidak memberi efek negatif yang merugikan bagi responden, sehingga hipnosis dianjurkan dilakukan untuk menurunkan tingkat kecemasan ibu postsectio caesarea.
\end{abstract}

Kata kunci : Hipnosis, tingkat kecemasan, ibu post sectio caesarea

\begin{abstract}
Sectio caesarea is one way of childbirth, the physical impact will cause abdominal pain and psychologically affect the fear and anxiety of the pain that is felt. Ongoing anxiety can cause stress, post partum blues and psychosis. One attempt to reduce anxiety levels is to use hypnosis. The purpose of this study to determine the effect of hypnosis on the anxiety level of post section caesarea mother in Marwah Singaparna Medika Citra Utama Hospital Tasikmalaya Regency.This study uses quasi experimental design, with one group pretest-postest design approach. The study was conducted on January 10, 2018 - March 10, 2018 with a population of 127 people and a sample of 30 people based on inclusion criteria (explain inclusion and exclusion criteria). The independent variable was hypnosis while the dependent variable is level of anxiety in post sectio caesarea mother.Data processing using Wilcoxon test. Based on statistical tests results there is a significant differences between pretest and postest with significance level $\rho$ value $0.001<0.05$, which means that hypnosis affects the level of anxiety. There was no negatve effect to respondence, so hypnosis can be suggested to reduce anxiety levels of post sectio caesarea mother.
\end{abstract}

Keywords : : Hypnosis, anxiety level, post sectio caesarea mother

\section{PENDAHULUAN}

Persalinan merupakan suatu hal yang dinanti oleh ibu hamil untuk dapat merasakan kebahagiaan menjadi seorang ibu. Persalinan sebagai rangkaian proses yang berakhir dengan pengeluaran konsepsi oleh ibu (Varney, 2007). Persalinan dapat dilakukan dengan dua cara, yaitu persalinan secara normal atau spontan (lahir melalui vagina) dan persalinan abnormal atau persalinan dengan bantuan suatu prosedur seperti sectio caesarea (SC) yaitu kelahiran janin melalui insisi di dinding abdomen dan dinding uterus (Alexanderet al., 2013).

Data World Health Organiżation (WHO) tahun 2015 selama hampir 30 tahun tingkat persalinan dengan SC menjadi $10 \%$ sampai $15 \%$ dari semua proses persalinan di negara-negara berkembang (Utami, 2016). Menurut Gibbson, WHO 
menetapkan standar rata-rata sectio caesarea di sebuah negara sekitar 5-15\% per 1000 kelahiran di dunia. Rumah Sakit pemerintah kira-kira $11 \%$ sementara Rumah Sakit swasta biasa lebih dari 30\% (Aprina, 2016).

Hasil Riset Kesehatan Dasar (Riskesdas) tahun 2013 menunjukkan bahwa jumlah persalinan dengan $S C$ di Indonesia 9,8\% dan di daerah Jawa Barat sebanyak 7,8\% (Kemenkes RI, 2013). Data yang terdapat dalam hasil Riskesdas Jawa Barat tahun 2013 persentase persalinan dengan SC di Kabupaten Tasikmalaya adalah 0,8\% (Kemenkes RI, 2013). Rumah Sakit Singaparna Medika Citrautama (SMC) Kabupaten Tasikmalaya adalah Rumah Sakit rujukan Kabupaten Tasikmalaya, dengan peningkatan angka SC dari tahun 2016 sampai 10 bulan terakhir tahun 2017, sebanyak 1064 orang dengan persalinan SC dan 974 persalinan spontan pada tahun 2016. Bulan Januari sampai Oktober tahun 2017 terdapat 1064 ibu dengan persalinan SC dan 865 persalinan spontan (Rekam Medik, 2017).

Secara fisik tindakan SC menyebabkan nyeri pada abdomen. Nyeri yang berasal dari luka operasi. Rasa nyeri meningkat pada hari pertama post operasi SC. Secara psikologis tindakan SC berdampak terhadap rasa takut dan cemas terhadap nyeri yang dirasakan setelah analgetik hilang. Menurut Manurung dalam Utami (2009), SC juga memberikan dampak negatif terhadap konsep diri ibu. Hal ini dikarenakan ibu dapat kehilangan pengalaman melahirkan secara normal serta kehilangan harga diri yang terkait dengan perubahan citra tubuh akibat tindakan operasi. Penelitian Heryanti dan Dara dalam Pawatte dkk (2013) membuktikan ibu yang bersalin dengan metode SC memiliki tingkat kecemasan yang lebih tinggi dibandingkan ibu yang bersalin spontan. Kecemasan dan nyeri pada post SC-saling mempengaruhi. Potter dan Perry dalam Syahputra (2013) mengatakan hubungan nyeri terhadap kecemasan bersifat kompleks. Kecemasan sering kali meningkatkan persepsi nyeri, tetapi nyeri juga dapat menimbulkan satu perasaan cemas. Stimulus nyeri mengaktifkan bagian sistem limbik yang diyakini mengendalikan emosi seseorang khususnya kecemasan. Sistem limbik dapat memproses reaksi emosi terhadap nyeri, yakni memperburuk atau menghilangkan nyeri. Rasa cemas yang berkelanjutan dapat menyebabkan stres, post partum blues bahkan psikosis yang menyebabkan ibu tidak dapat menjalankan perannya sebagai ibu bagi bayinya.

Kecemasan dapat diatasi dengan penatalaksanaan cemas. Adapun 2 cara penatalaksanaan cemas yaitu dengan cara farmakologi dan non-farmakologi. Secara farmakologis dapat diatasi dengan menggunakan obat anti kecemasan yang tidak dianjurkan untuk penggunaan jangka panjang seperti buspiron dan antidepresan. Terapi non-farmakologi seperti distraksi, relaksasi progresif, meditasi dan hipnosis (Manurung, 2016). Salah satu upaya untuk mengurangi tingkat kecemasan adalah dengan hipnosis. Berdasarkan penelitian yang dilakukan oleh Triyani dkk (2016) tentang Pengaruh Hipnosis Terhadap Tingkat Kecemasan Ibu Hamil Nullipara Triwulan III dalam Persiapan Menghadapi Persalinan. Ditunjukkan bahwa terdapat perbedaan hasil sebelum dan sesudah dilakukan hipnosis antara tingkat kecemasan pada sampel "kasus" dengan tingkat kecemasan 2,55 dengan standar deviasi 1,986. Sedangkan rata-rata tingkat kecemasan pada sampel "kontrol" adalah sebesar 9,60 dengan standar deviasi 6,004. Hasil uji statistik menunjukkan nilai $p$ value 0,000, yang berarti bahwa terdapat perbedaan yang bermakna antara rata-rata tingkat kecemasan pada sampel "kasus" dan "kontrol". Pada saat melakukan hipnosis, gelombang otak kita dapat mencapai gelombang alfa, pada kondisi ini tubuh dan pikiran kita rileks, tapi tetap waspada. Tubuh mengeluarkan hormon serotonin dan endorfin, yang bermanfaat untuk menekan hormon ACTH, hormon yang mengatur sekresi kortisol penyebab stres (Hypno-birthing Indonesia, 2016).

Berdasarkan studi pendahuluan yang penulis lakukan pada tanggal 6 Desember 2017 di Ruang Marwah Rumah Sakit Singaparna Medika Citrautama (SMC) Kabupaten Tasikmalaya, belum pernah diadakan penelitian tentang pengaruh hipnosis terhadap tingkat kecemasan ibu post SC. Peneliti mendapatkan data ibu melahirkan secara SC berjumlah 234 orang dalam kurun waktu 3 bulan terakhir (Agustus-Oktober 2017). Setelah mewawancarai ibu post SC, peneliti mendapatkan 7 orang ibu post SC dengan 3 orang tingkat kecemasan sedang, 2 
orang tingkat kecemasan tidak ada, 1 orang tingkat kecemasan berat dan 1 orang dengan tingkat kecemasan ringan.

Berdasarkan latar belakang tersebut, peneliti tertarik untuk melakukan penelitian tentang "Pengaruh Hipnosis terhadap Tingkat Kecemasan pada lbu Post Sectio Caesarea di Ruang Marwah Rumah Sakit Singaparna Medika Citrautama (SMC) Kabupaten Tasikmalaya Tahun 2018". Adapun perbedaan penelitian ini dengan penelitian-penelitian sebelumnya terdapat pada variable terikatnya. Dalam penelitian Triyani dkk, variable terikat adalah tingkat kecemasan ibu hamil nullipara triwulan III dan pada penelitian Niraski dkk variabel terikat adalah tingkat nyeri ibu post SC sedangkan dalam penelitian yang dilakukan penulis adalah tingkat kecemasan ibu post SC.

\section{METODE PENELITIAN}

Jenis penelitian ini adalah penelitian eksperimen. Penelitian ini termasuk dalam penelitian quasi experimental design, dengan rancangan one group pretestpostest design. Pada desain ini terdapat satu kelompok yang diberi perlakuan hipnosis dan dilakukan pretest dan posttes. Penelitian ini telah dilaksanakan pada 10 Januari 2018 - 10 Maret 2018 di Ruang Marwah Rumah Sakit Singaparna Medika Citrautama (SMC) Kabupaten Tasikmalaya. Populasi dalam penelitian ini adalah seluruh ibu postsectio caesarea di Ruang Marwah RS SMC Kabupaten Tasikmalaya dalam kurun waktu 10 Januari 2018 - 10 Maret 2018, sampel diambil sebanyak 30 orang dengan teknik sampling menggunakan purposive sampling. Kriteria inklusi pada penelitian ini yaitu, ibu yang dirawat di Ruang Marwah, Ruang Nifas yang memiliki pasien SC terbanyak, RS SMC Kabupaten Tasikmalaya. Ibu yang pertama kali melakukan sectiocaesarea, ibu bersedia menjadi responden, ibu mengikuti semua rangkaian penelitian dari pretest hingga posttest dan tidak mempunyai penyakit berat, seperti penyakit jantung dan paru-paru. Kriteria eksklusi pada penelitian ini yaitu, ibu yang tidak dapat diinduksi hipnosis, kurang konsentrasi.

Peneliti memberikan inform consent pada calon responden sebelum dilakukan kegiatan penelitian dilakukan. Peneliti memberitahukan tentang pelaksanaan penelitian pada ibu hamil, memberikan penjelasan tentang tujuan, proses dan manfaat penelitian pada responden. Responden mengisi kuesioner pretest untuk menilai tingkat kecemasannya, yang telah dibagikan dan dijelaskan oleh peneliti, pada saat $>24$ jam setelah responden dilakukan operasi SC. Responden mengisi form hipnoterapi dan dilakukan hipnosis 1 kali oleh peneliti, dengan tahapan prainduksi, induksi, isolasi, tes, konsolidasi, implantasi dan terminasi, sebelumnya peneliti telah mengikuti pelatihan basic clinical hypnosis. Pengisian kuesioner posttest pada saat 24 jam setelah responden dilakukan pretest. Tingkat Kecemasan pada responden diukur dengan Skala Hamilton Anxiety Rating Scale (HARS) (Liangan, 2013).

Analisis data dalam penelitian ini menggunakan analisa univariat yaitu menganalisis tiap variabel penelitian yang ada secara deskriptif dengan menghitung distribusi frekuensi dan analisis bivariat menggunakan uji Wilcoxon, tidak dilakukan uji normalitas data karena berskala data ordinal, untuk melihat pengaruh hipnosis terhadap tingkat kecemasan pada ibu postsectio caesarea.

\section{HASIL PENELITIAN}

1. Analisis Univariat

Tabel 1. Distribusi Frekuensi Tingkat Kecemasan Pada Ibu Post SC

\begin{tabular}{lcccc}
\hline \multicolumn{1}{c}{ Tingkat } & \multicolumn{2}{c}{ Sebelum } & \multicolumn{2}{c}{ Setelah } \\
Kecemasan & $\mathbf{f}$ & $\%$ & $\mathbf{f}$ & $\%$ \\
\hline $\begin{array}{l}\text { Tidak Ada } \\
\text { Kecemasan }\end{array}$ & 0 & 0 & 3 & 10 \\
$\begin{array}{l}\text { Kecemasan } \\
\text { Ringan }\end{array}$ & 2 & 6,7 & 0 & 0 \\
$\begin{array}{l}\text { Kecemasan } \\
\begin{array}{l}\text { Sedang } \\
\text { Kecemasan }\end{array}\end{array}$ & 26 & 86,7 & 27 & 90 \\
$\begin{array}{l}\text { Berat } \\
\quad \text { Jumlah }\end{array}$ & $\mathbf{3 0}$ & $\mathbf{1 0 0}$ & $\mathbf{3 0}$ & $\mathbf{1 0 0}$ \\
\hline
\end{tabular}

Berdasarkan tabel 1 di atas, diketahui bahwa tingkat kecemasan ibu post SC di RS SMC Kabupaten Tasikmalaya sebelum diberikan perlakuan hipnosis sebagian besar mengalami tingkat kecemasan sedang yaitu sebanyak 26 orang $(86,7 \%)$ dan ada 2 orang (6,7\%) untuk masing-masing yang mengalami kecemasan berat dan kecemasan ringan. Tingkat kecemasan ibu post SC setelah diberikan perlakuan hipnosis sebagian besar ibu mengalami tingkat kecemasan sedang yaitu sebanyak 27 orang $(90 \%)$ dan 
terdapat 3 orang (10\%) ibu yang tidak mengalami kecemasan.

\section{Analisis Bivariat}

Tabel 2. Rata-Rata Nilai Pretest dan Postest Perlakuan Hipnosis Terhadap Kecemasan Ibu Post SC

\begin{tabular}{ccc}
\hline Perlakuan Hipnosis & Rata-Rata & $\boldsymbol{\rho}$ value \\
\hline Pretest & 20,63 & \multirow{2}{*}{0,001} \\
Posttest & 10,50 & \\
\hline
\end{tabular}

Berdasarkan tabel 2 di atas, diketahui bahwa pada saat pretest kelompok perlakuan hipnosis memiliki nilai rata-rata 20,63 dan nilai posttest 10,50 , hal ini menunjukkan bahwa terdapat perbedaan antara sebelum dan sesudah dilakukan pemberian hipnosis dengan penurunan sebanyak 2 kali lipat. Hasil uji statistik Wilcoxon diperoleh nilai $\rho$ value $=0,001$. Nilai $\rho$ value $<0,05$, maka Ha diterima. Hasil ini menunjukan terdapat perbedaan yang signifikan antara sebelum dan sesudah pemberian hipnosis terhadap tingkat kecemasan ibu post SC. Maka dapat disimpulkan bahwa ada pengaruh hipnosis terhadap tingkat kecemasan pada ibu postsectio caesarea di Ruang Marwah Rumah Sakit Singaparna Medika Citrautama (SMC) Kabupaten Tasikmalaya Tahun 2018.

\section{PEMBAHASAN}

1. Gambaran Tingkat Kecemasan Pada Ibu PostSectioCaesarea Sebelum dan Setelah Dilakukan dan yang Tidak Dilakukan Hipnosis di Ruang Marwah Menurut Kaplan, Sadock dan Grebb dalam Manurung (2016), kecemasan adalah respon terhadap situasi tertentu yang mengancam dan merupakan hal yang normal terjadi menyertai perkembangan, perubahan, pengalaman baru atau yang belum pernah terjadi. Menurut Stuart dan Sundeen dalam Manurung (2016) bahwa cemas memiliki tingkatan, yaitu cemas ringan, cemas sedang, cemas berat dan panic.

Berdasarkan hasil penelitian, ibu yang telah menjalani operasi sectio caesarea mengalami kecemasan tingkat sedang dan hal ini sesuai dengan Page, yaitu kondisi ibu yang gelisah, perasaannya tidak nyaman akibat nyeri atau ngilu perut ibu dari luka operasi.
2. Pengaruh Hipnosis Terhadap Tingkat Kecemasan Pada lbu Post Sectio Caesarea di Ruang Marwah Berdasarkan hasil penelitian pengaruh hipnosis terhadap tingkat kecemasan pada ibu postsectiocaesarea di Ruang Marwah Rumah Sakit Singaparna Medika Citrautama (SMC) Kabupaten Tasikmalaya tahun 2018 dan diuji oleh alat bantu hitung statistik menggunakan Wilcoxon didapatkan hasil ada pengaruh hipnosis terhadap tingkat kecemasan ibu post SC dengan $\rho$ value $=0,001$.

Alam bawah sadar adalah bagian yang paling dominan untuk memengaruhi perilaku manusia, menurut pakar $88 \%$ perilaku manusia dipengaruhi oleh pikiran bawah sadar. Hipnosis dapat membantu kita untuk meningkatkan kendali terhadap pikiran bawah sadar. Sehingga dapat digunakan untuk kesembuhan, kesuksesan dan pengendalian diri (Laksana, 2017). Hipnosis merupakan salah satu komunikasi yang bertujuan untuk memengaruhi seseorang sehingga mengubah tingkat kesadarannya. Pada saat melakukan hipnosis, gelombang otak dapat mencapai gelombang alfa, pada kondisi ini tubuh dan pikiran rileks, tapi tetap waspada. Tubuh mengeluarkan hormon serotonin dan endorphin, yang bermanfaat untuk menekan hormon ACTH (Hypno-birthing Indonesia, 2016).

Faktor yang memengaruhi adaptasi psikologis pada ibu nifas, yaitu usia, bertambahnya usia ibu akan memengaruhi dalam pengendalian emosinya, semakin tua semakin dapat mengendalikan karena pengalaman yang telah dilalui lebih banyak dan semakin muda pengendalian emosi belum stabil. Keinginan individu, keinginan seorang ibu yang tidak sesuai dengan keadaannya kadang menghambat dalam proses menjadi orang tua, contohnya ibu ingin menyusui anaknya namun ASI yang dimiliki ibu sedikit atau tidak keluar. Dukungan sosial, dukungan dari orang tua, saudara, kakek-nenek, dan orang terdekat lainnya sangat berpengaruh terhadap semangat hidup ibu (Novita, 2011).

Penelitian Niraski dkk (2015) mengenai pengaruh hipnoterapi terhadap tingkat nyeri pada ibu postsectiocaesarea di 
RSB Jeumpa Pontianak tahun 2015, dalam penelitiannya dapat disimpulkan bahwa terdapat perbedaan tingkat nyeri pada kelompok intervensi dan kontrol dengan $\rho$ value $=0,001$.

Berdasarkan hasil penelitian dan para ahli, hipnosis terbukti berpengaruh dan lebih cepat menurunkan kecemasan pada ibu post SC dibandingkan dengan tanpa hipnosis. Kondisi diri ibu yang fokus dan tenang membuat perasaan nyeri dan semua pikiran yang ibu pikirkan teralihkan, serta ibu mengafirmasikan hal-hal yang baik ke dalam alam bawah sadar ibu. Namun dalam penelitian ini faktor-faktor yang memengaruhi adaptasi psikologis ibu tidak dikendalikan seperti keinginan ibu dan dukungan sosial karena keinginan dan dukungan sosial dari ibu maupun keluarga sifatnya berbeda-beda dan usia juga tidak dikendalikan oleh peneliti. Hasil dari penelitian ini tidak memberi efek negatif yang merugikan bagi responden, sehingga menurut peneliti hipnosis dianjurkan untuk menurukan tingkat kecemasan ibu post SC.

\section{SIMPULAN DAN SARAN}

\section{Kesimpulan}

Hasil penelitian yang telah dilakukan mengenai pengaruh hipnosis terhadap tingkat kecemasan pada ibu post SC di Ruang Marwah Rumah Sakit Singaparna Medika Citrautama (SMC) Kabupaten Tasikmalaya tahun 2018 dapat disimpulkan sebagai berikut,

1. Gambaran tingkat kecemasan pada ibu post $S C$ yang diberikan hipnosis, tingkat kecemasan terbanyak sebelum dan setelah dilakukan hipnosis yaitu tingkat kecemasan sedang.

2. Ada pengaruh hipnosis terhadap tingkat kecemasan pada ibu post SC di Ruang Marwah Rumah Sakit Singaparna Medika Citrautama (SMC) Kabupaten Tasikmalaya Tahun 2018 dengan nilai pvalue $=0,001$.

\section{Saran}

1. Institusi Pendidikan: Diharapkan hasil penelitian ini dapat diterapkanpada proses belajar mengajar sebagai upaya meningkatkan pengetahuan dan kemampuan peserta didik serta dapat memberikan masukan bagi perkembangan ilmu pengetahuan dan landasan pemikiran dalam melaksanakan penelitian selanjutnya.
2. Mahasiswa atau peneliti selanjutnya: Diharapkan mahasiswa yang melakukan penelitian selanjutnya dapat mengendalikan faktor-faktor yang memengaruhi adaptasi psikologis ibu nifas, serta diharapkan untuk menyiapkan dan mengondisikan tempat berlangsungnya hipnosis.

3. Tenaga Kesehatan: Diharapkan tenaga kesehatan dapat memberikan kontribusi dengan melakukan hipnosis dalam meningkatkan kualitas pelayanan serta untuk meningkatkan kenyamanan pada ibu post SC.

\section{DAFTAR PUSTAKA}

Aprina, Anita Puri. 2016.Faktor-faktor yang berhubungan dengan persalinan sectio caesareadi RSUD Dr. H. Abdul Moeloek Provinsi Lampung, Jurnal Kesehatan, Vol VII/1, Hal. 9096

Alexander, J. M.,Bloom, S. T.,Caey, B. M.,Cunningham, F. G.,Gant, N. F.,Leveno, K. J., . . . Yost, P. N. 2013. Obstetri William Panduan Ringkas,. (Brahm U penerjemah). Egi K. Y dan Nike B. S (Ed.). Edisi 21. Jakarta: EGC.

Kementerian Kesehatan RI. 2013.Riskesdas dalam angka Provinsi Jawa Barat 2013.Jakarta: Lembaga Penerbitan Badan Penelitian dan Pengembangan Kesehatan Kementerian Kesehatan RI.

Kementerian Kesehatan RI. 2013. Riskesdas Republik Indonesia 2013. Jakarta: Lembaga Penerbitan Badan Penelitian dan Pengembangan Kesehatan Kementerian Kesehatan RI.

Hypno-birthing Indonesia. 2016. Modul panduan pelatihan basic hypnosis dan hypno-birthing. Modul disampaikan pada pelatihan Hypno-birthing, Tasikmalaya

Laksana, H. 2017. Hypnotic power rahasi membaca dan memengaruhi isi hati dan pikiran orang lain dengan hipnotis. Yogyakarta: Araska.

Liangan, Raymon. 2013. HARS PenilaianKecemasan. https://www.scribd.com;diaksestang gal 18 November 2017. 
Manurung, N. 2016. Terapi reminiscence, Jakarta Timur: CV. Trans Info Media.

Niraski, V. 2015. Pengaruh hipnoterapi terhadap tingkat nyeri pada ibu post sectio caesareadi RSB Jeumpa Pontianak Tahun 2015, Proners, Vol $1 / 3$

Novita, R. 2011.Keperawatan maternitas. Cet. I. Bogor: Ghalia Indonesia

Pawatte, I., Pali, C., Opod, H. 2013. Perbedaan tingkat kecemasan pada ibu pre seksio caesarea di RSIA Kasih Ibu dan RSUP. Prof. Dr. R. D. Kandou Manado, Jurnal Kedokteran Komunitas dan Tropik, Vol 1/3, Hal. 107-112

Rekam Medik. 2017.Tasikmalaya: Rumah Sakit Singaparna Medika Citrautama Kabupaten Tasikmalaya

Syahputra, H., Jumaini., Novayelinda, R. 2013. Hubungan tingkat nyeri dengan tingkat kecemasan pada pasien fraktur tulang panjang di RSUD Arifin Achmad Pekanbaru.http://repository.unri.ac.i $d$; diakses tanggal 9 Desember 2017.

Triyani, S., Fatimah., A. 2016. Pengaruh hypnosis terhadap tingkat kecemasan ibu hamil nullipara triwulan III dalam persiapan menghadapi persalinan, The Southeast Asian Journal of Midwifery, Vol 2/1, Hal 24-32

Utami, S. 2016. Efektivitas aromaterapi bitter orange terhadap nyeri post partum sectio caesarea, Unnes Journal of Public Health, Vol 5/4, Hal.316-323.

Varney, H. 2007. Buku Ajar AsuhanKebidananEdisi.4 Vol. 2. Jakarta: EGC. 